\title{
Gammadózis teljesítmény-eloszlási térkép készítése kis méretű drón alkalmazásával
}

\section{Bevezetés}

Számos esetben igen hasznosnak bizonyulhat egy adott terület dózisteljesítmény eloszlásának ismerete. Ilyen lehet például egy átmeneti nukleáris hulladéktározó, ahol pontosan és gyorsan kimutatható az esetleges szivárgás, vagy olyan laboratóriumok szellőzői és azok környéke, ahol izotópos preparátumokkal dolgoznak. Hasonlóképpen hatékony ellenőrzést tesz lehetővé egy balesetet szenvedett nukleáris létesítmény monitorozásában az adott területről időközönként készített sugáreloszlási térkép.

Hasonló kísérletek már történtek drónra szerelt érzékelőkkel [1]. Ebben az esetben szcintillációs detektort alkalmazva gamma spektrumot készítettek a kutatók, így lehetőség nyílt a sugárforrás anyagának meghatározására is. A kísérlet során szűk ( $80 \times 40$ méter) területet vizsgáltak $1 \mathrm{~m} / \mathrm{s}$ sebességű repüléssel, több magasságon.

Egy másik kutatás eredménye szerint [2] látható tartományú kameraképpel kombinált sugárzási képet készítettek, így a sugárforrás helye a képre vetítve jelent meg, ami nagymértékben megkönnyítette a felfedezett forrás megtalálását. A sugárzás kimutatására itt is szcintillációs detektort építettek be, amivel a kísérleti minta felett 1,5 méterre kellett repülni.

Egy feltételezett katasztrófát szimulálva, a kutatók robotrepülő (UAV) és földi robotjármű (UGV) kooperációjával kialakított sugárforrás-felderítő rendszert készítettek [3]. A program lényege, hogy a repülő eszközzel leszűkítik a fellelt sugárforrás helyét, majd az adatokat a földi járműnek átadva, az pontosan lokalizálja azt. A kísérletek során szintén szcintillációs detektorral történt a sugárzás kimutatása.

Számos további kutatási eredmény ismert, amelyek során robotrepülőgépre szerelt sugárzás-érzékelővel egy adott területről sugárzási képet készítettek [4] [5] [6]. Ezen kísérletek során jellemző módon szcintillációs detektort vagy félvezető alapú sugárdetektort alkalmaztak. A szcintillációs detektorok relatíve nagy tömegüek, így az értékes repülési időt jelentős mértékben csökkentik. A félvezető alapú detektorok ugyan könnyűek, de magas áruk mellett érzékenységük nem haladja meg a hagyományos (szcintillációs vagy gázionizációs) detektorok érzékenységét.

A nukleáris medicinában ismert gammakamerák által készített felvételek analógiájára készíthető olyan eszköz, amely szabad területen képes sugárzási intenzitásképet készíteni. Ezek az eszközök azonban szcintillációs detektorral rendelkeznek, és a képalkotáshoz is nagy tömegü ólom kolimátort alkalmaznak. Éppen ezért ezt a módszert kis méretű robotrepülőgépeken közvetlenül alkalmazni nem lehet. Egy új eszköz megtervezésére volt szükség, amelynek elvárt minőségi jellemzői a következők:

- Az összefüggő vizsgált terület legalább 5000 m² vagy annál nagyobb.

- A készített felvétel felbontása legyen olyan, hogy minimum 10 méter távolságból lokalizálható legyen a sugárforrás egy személygépkocsi által lefedett területen.

- Az elkészített felvétel (sugárzási térkép) legyen kalibrált és georeferált.

- A detektor érzékenysége tegye lehetővé minimum 10 méter távolságból egy egészségügyi határértéken sugárzó 1 cm³-es, legalább $200 \mu$ Svh aktivitású minta kimutatását.

\section{DeteKTORRENDSZER}

Az önálló repülési feladatokat elvégezni képes, kis méretű repülőeszközre felszerelhető gammadetektor kiválasztása során alapvetően két szempontot kellett figyelembe venni.

- A detektor tömege kritikus, mivel a kis méretű drónok hasznostömeg-szállítási képessége erősen korláto-
ÖSSZEFOGLALÁS: Kis méretú drónok autonóm repülésük során többek között müholdas navigációt (legelterjedtebben GPS) alkalmaznak. Ez azt jelenti, hogy a repülés teljes idôtartamáról típusonként eltérő gyakorisággal, de rendszeres koordináta információk rögzíthetők. Számos légi fényképezés alkalmazás használja fel ezen adatokat. Amennyiben a drónt érzékeny gamma detektorral látjuk el, a gamma mérési adatokhoz a repülési adatok koordinátái hozzá rendelhetők. Ezen információcsoportok lehetőséget biztosítanak egy terület gamma detektoros pásztázása során annak $\gamma$-dózis teljesítmény-eloszlásának meghatározására. A módszer segítséget nyújthat gammasugárzást kibocsátó illegálisan tárolt vagy szállított minták felderítésére, lokalizálására. Az értekezés egy gyakorlati kísérleteken alapuló rendszert mutat be, amely lehetővé teszi kis dózisú minták lokalizálását, illetve egy adott terület kvalitatív gammasugárzás-térkép elkészitését. A módszer elsősorban nyilt terepi körülmények között, alacsony aktivitású gammasugárzók felderítésére alkalmazható.

KULCSSZAVAK: Gammasugárzás, eloszlási térkép, sugárforrás felderítés, drónos sugárfelderítés
ABSTRACT: During their flight, small-sized drones use satelite navigation (the most widespread is GPS). This means that frequent coordinate information can be recorded in the entire duration of the flight with varying frequency according to the type. Several aerial photography applications utilize these data. If the drone is equipped with a sensitive gamma detector the flight coordinates can be assigned to gamma measurement data. These groups of data provide an opportunity during the gamma detector-based scan of an area to determine its radiation distribution. The method can provide help to explore and localize patterns, stored or transported illegally, which exhaust gamma radiation. This paper introduces a system based on practical experiments which makes the localization of small-dose patterns possible as well as the creation of a qualitative gamma radiation map in a given area. The method can be primarily used in terrain circumstances, first and foremost to detect low-activity gamma radiators.

KEY WORDS: Gamma radiation, distribution map, radiation source detection, radiation detection using a drone

\footnotetext{
Dr. habil. Molnár András Óbudai Egyetem, Neumann János Informatikai Kar molnar@uni-obuda.hu. ORCID: 0000-0003-4330-6547
} 
zott. Itt jellemzően 500 gramm vagy attól kisebb tömegű detektorrendszer jöhet számításba. Fontos megjegyezni, hogy nem elég a detektort levegőbe emelni, hanem azzal a lehető leghosszabb ideig repülni szükséges. A minimálisan elvált repülési idő 15 perc. A fent megfogalmazott feltételeknek a gáz-ionizációs detektorok közül a Geiger-Müller számláló csövek megfelelnek.

- A detektor érzékenysége, illetve hatásfoka a relatív nagy távolságból végezhető mérések okán szintén kiemelt szempont. E tekintetben egyes szcintillációs detektorok lényegesen jobb detektálási hatásfokot nyújthatnak a gázionizációs detektoroknál. További előnyös detektor típus lehet a félvezető-alapú detektor, de ennek költsége az azonos érzékenységet biztosító GM csőhöz viszonyítva igen magas.

A lehetséges detektorok kiválasztása során - mérlegelve a fenti szempontokon felül az eszköz várható költségvonzatát is -, a nagy méretű GM csőre esett a választás. A nagy méret a kellő érzékenységet, a GM cső pedig az alacsony tömeget biztosította, emiatt esett rájuk a választás. A prototípus detektor a kísérletek helyszínén $80 \mathrm{cpm}$ (beütés per perc) átlagos értékeket mért. A detektorhoz egy mikrokontrollert kapcsoltunk. Ennek feladata a mért adatok rögzítése úgy, hogy egy adatrekord tartalmazza a percenkénti beütésszámot, a méréshez kapcsolt időpillanatot (időbélyeg) és a mérés GPS-koordinátáját. Mivel a drón rendszere másodpercenként biztosított pontos GPSkoordinátákat, a beütésszámot egy speciális időablakban gyűjtve annak átlaga alapján rögzítettük. Az alkalmazott időablak mindig az utolsó kb. 15 másodperc beütéseinek számát tartalmazta. Az az adat, amely 15 másodpercnél korábbi, kikerült az átlagoló ablakból, miközben minden új beütés bekerült a helyére. Ez a módszer biztosította, hogy a minden másodpercben rögzített beütésszám statisztikailag is értelmezhető mennyiségű adatból álljon elő. Ugyanakkor a 15 másodperces gyűjtőablak, a haladó drón esetében a koordinátákhoz rendelt beütések koordináta-korrekcióját is szükségessé teszi, amit a későbbi feldolgozás során mindenképpen figyelembe kell venni.

A beépített GM cső releváns technikai paraméterei a következők:

- effektív hosszúság: 298.5 mm;

- effektív átmérő: 20.0 mm;

- gamma érzékenység Co 60 izotópra: 180 cps/mR/h;

- tömege: $150 \mathrm{~g}$.

A detektorrendszer az alábbi adatstruktúrát hozza létre:

\begin{tabular}{|l|l|l|l|l|l|l|l|l|l|l|l|l|l|} 
A & B & C & D & E & F & G & H & I & J & K & L & M & N \\
\hline
\end{tabular}

$A z$ egyes mezők jelentése a következő:

A: Mondat-azonosító (jelen esetben mindig \$CGPS);

B: GPS-dátum (nap xx, hónap yy, év zz);

C: GPS-idő (óra xx, perc yy, másodperc zz.zz);

D: GPS-státusz (jelen esetben GPSEN);

E: Szélességi fok (fok xx, perc yy.yyyy);

$F$ : Félgömb (északi $N$ vagy déli $S$ );

G: Hosszúsági fok (fok xxx, perc yy.yyyy);

$\mathrm{H}$ : Nyugat/kelet (E vagy W);

I: Tengerszint feletti magasság légnyomás alapján (méter xxx.xx);

J: Tengerszint feletti magasság GPS-mérés alapján (méter xxx.xx);

K: Számított sugárzás $(\mathrm{mR} / \mathrm{h})$;

L: Időegység alatt detektált beütések száma (az időegység változhat, értéke az $M$ mezőből olvasható ki);

$M$ : A beütések számlálásának időegysége (másodperc $x x . x x x x x x)$;

$\mathrm{N}$ : Ellenőrző összeg.
Példa egy mondatra:

\$CGPS, 170712,023259.746,GPSEN,4732.0185,N,0190

$2.0008, E, 175.40,175.40,0.0074,19,14.244000,{ }^{*} 77$

\section{ELŐKÍSÉRLETEK}

Az elkészült mérőegységet kísérleti céllal egy saját fejlesztésű robotrepülőgépre integráltuk (1. ábra). A repülőgép képes volt előre programozott repülési feladatot autonóm módon végrehajtani [7]. A repülések több kísérlet elvégzését célozták meg, amelyek között a repülés során mérhető háttérsugárzás vizsgálata is szerepelt.

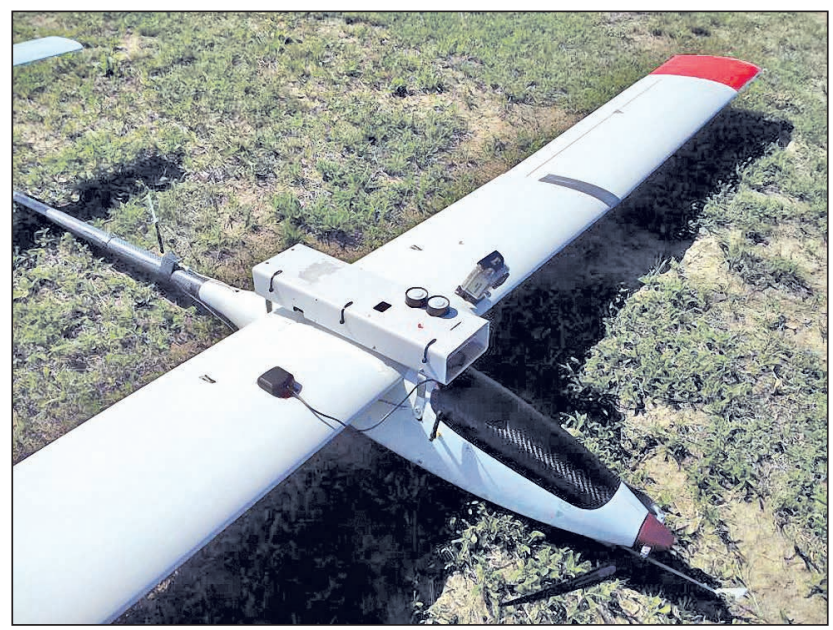

1. ábra. A Chelidon nevű, saját fejlesztésű robotrepülőgépre szerelt mérömodul

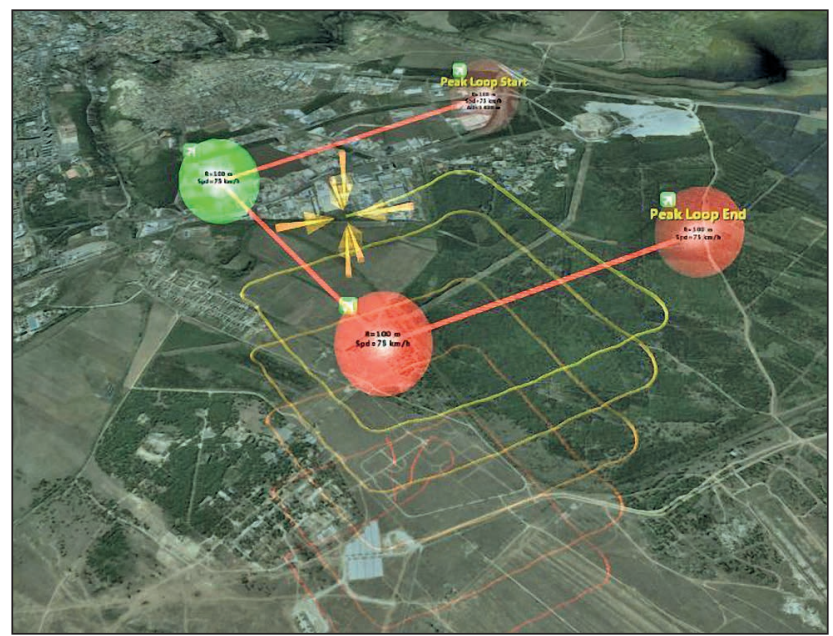

2. ábra. A Várpalota légterében történt, 500 méteres emelkedés során végzett mérés repülési nyomvonala

A 2. ábra egy 500 méter magasságú repülés nyomvonalát ábrázolja. A repülés célja az volt, hogy a repülőgép egy jól definiált területen emelkedjen a fedélzetére rögzített műszerekkel 500 méter magasságra, majd ugyanazon terület felett ereszkedjen vissza [8]. Így rendelkezésünkre álltak az emelkedés során mért adatok, illetve változások, amiket a merülés során rögzített adatokkal össze tudtunk hasonlítani. A repülés mérési eredményeit a 3 . ábra grafikonjai szemléltetik.

A grafikonon látható narancssárga görbe a háttérsugárzást szemlélteti a magasság függvényében. A detektor 


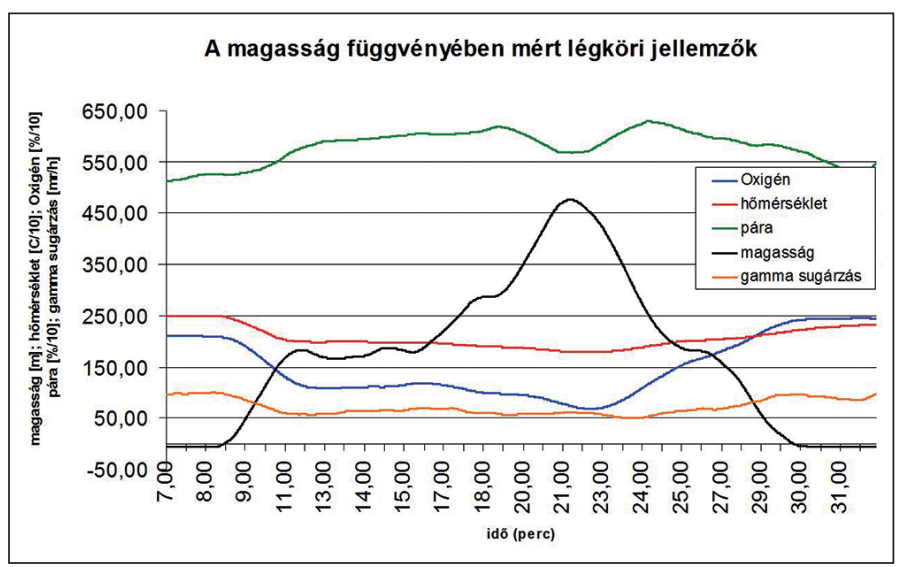

3. ábra. 500 méteres emelkedés komponenseinek diagramjai

kellően érzékenynek bizonyult ahhoz, hogy a föld háttérsugárzását érzékelni lehessen vele.

Mivel az alkalmazott repülőgép sebessége $65-90 \mathrm{~km} / \mathrm{h}$ ( 18-25 m/s), az eredeti célok eléréséhez hordozóeszközként nem alkalmazható. Ahhoz, hogy egy terület gammasugárzás-eloszlását a rendelkezésünkre álló GM csővel kellő érzékenységgel feltérképezhessük, a detektort hoszszabb ideig kell egy adott térrészen tartani. Ehhez egy lassan is repülni képes hordozót kellett keresni. A multirotoros drónok erre a célra alkalmas eszköznek bizonyultak. A további kísérleteket egy négyrotoros multikopterrel végeztük, amely szintén alkalmas volt programozott útvonal önálló lerepülésére. A kész detektormodult egy DJI Inspire drónra rögzítettük (4. ábra). Az eszköz minimális autonóm repülési sebessége $2 \mathrm{~m} / \mathrm{s}$.

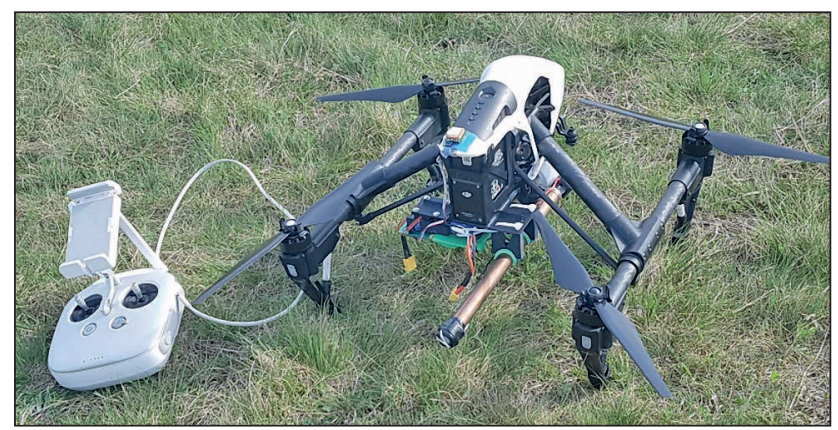

4. ábra. A GM detektormodullal felszerelt Inspire drón

\section{A mÉRÉSI ELJÁRÁs}

A mérés kidolgozása során alapvetően a klasszikus légi fényképezést, azon belül is az egymást átfedő nagyobb terület fényképezési eljárását vettük alapul. Ennek lényege, hogy a drónt olyan repülési pályán kell vezetni, amely a vizsgált területet úgy fedi le, hogy a közben készített, közel függőleges tengelyű képek egymást minden irányból átfedve a teljes területet lefedjék. Az eljárás legegyszerübben egy úgynevezett meander pályán történő repülésekből áll úgy, hogy a repülés során egységnyi időközönként készülnek a fényképfelvételek. Természetesen a pálya magasságát, a párhuzamos szakaszok távolságát, valamint a fényképfelvételek gyakoriságát a kamera optikai képességeihez és sebességéhez kell hangolni.

A $\gamma$-dózis teljesítmény-eloszlás meghatározásához a légi felderítés során folyamatosan mérni kell az adott repülési ponton a sugárzást, vagy ami azzal egyenértékű, a beütés- számot. A mérés későbbi kiértékelhetősége szempontjából lényeges, hogy a repülés egyenletes sebességgel, állandó magasságon történjen. Ezzel biztosítható, hogy a detektor által mért adatok minden repülési pont esetében egymással összehasonlíthatók legyenek. Mivel a kvantitatív sugárzásmérés a kísérlet ezen fázisában nem volt elvárt, elegendő volt biztosítani a mérési időtartam alatt az egyenletes mozgást, az állandó magasságot, valamint a detektor elektronikai egységének stabilitását.

A DJI Inspire drónra azért esett a választás, mert repülése nagyon stabil, képes programozott útvonalon automatikusan repülni. Ez a képesség biztosítja az egyenletes, egy magasságon történő repülést a mérés alatt. Valamint rendelkezik fedélzeti, stabilizált platformra rögzített nagy felbontású, torzításmentes kamerával. A kamerának köszönhetően elértük, hogy egyetlen repüléssel elkészül a terület fényképekből összeállított ortofotója és a detektor által mért adatokból kimutatható ugyanannak a területnek a relatív gammasugárzás-eloszlása.

Mivel az Inspire beépített kamerája minden felvételhez rögzíti a felvétel pillanatában mért GPS-adatokat, a képekből előállított ortofotó georeferált és kalibrált. Az ortofotó terepi felbontása $3 \mathrm{cmp} /$ pixel, a georeferálás pontossága tapasztalataink szerint jobb, mint 3 méter. Bár ez a pontosság a terepen elhelyezett referenciapontok segítségével pontosítható, jelen kísérelnél a 3 méteres megbízhatóság elegendő.

Tekintettel arra, hogy a gammadetektor mérési értékeihez is rögzítve vannak a GPS-adatok, az abból előállított intenzitástérkép hozzá illeszthető az ortofotóhoz. A két képi réteg egyszerű matematikai művelettel egymásra vetíthető, így vizualizálható a sugárforrás helye a térképen.

\section{A gammadózIS TELJESítMÉNY-ELOSZLÁSI TÉRKÉP ELŐÁLLíTÁSA}

A detektormodul a sugárzási adatokat a GM cső egységnyi idő alatt detektált beütésszámából számítja. Ez azt jelenti, hogy egy adott ponton - az eszközzel a mérés idejére meg kellene állni, de a megállások (terület feletti lebegés) nagyon sok energiát igényelnek, így rendkívül lerövidülne a berepülhető távolság, ami végül a vizsgált terület drasztikus csökkenését jelentené. Éppen ezért a hordozó folyamatos $2 \mathrm{~m} / \mathrm{s}$ sebességgel halad, miközben a detektormodul számítja a sugárzási értékeket. Ebből következik, hogy egy-egy mérési ponton meghatározott érték nem a GPS által rögzített ponthoz, hanem egy szakaszhoz tartozik. Ezért a mérési eredmények koordinátáit is korrigálni kell a hordozó sebességvektorával. A kísérlet jelen fázisában a korrekciót az átlagoló ablak idejének felével számítjuk, azaz 7,5 sec alatt megtett úttal korrigáljuk a mérési pont koordinátáját. Ez gyakorlatilag 15 méter korrekciót jelent a haladási iránnyal szemben.

$A z$ egyes mérések a terület felett diszkrét pontokban történnek. A területet lefedő intenzitás-eloszlás (sugárzáseloszlás) ábrázolása során feltételezzük, hogy az egyes mérési pontok környezetében is hasonló értékek mérhetők. Ebből adódóan a szomszédos mérési pontok értékeit a pontokat összekötő szakaszok mentén a mért értékek interpolációját számítjuk ki. Az interpoláció is diszkét értékeket ad, de az így létrejövő ponthalmaz pontjainak távolsága a mérési pontok egytizede.

Az interpolációval sűrített sugárzási adatokat (pontfelhő) konvolúciós szűrőkkel simítjuk. Ez abból a feltételezésből végezhető el, hogy a sugárzás értéke egy adott pont környezetében nem változik meg ugrásszerűen. Tekintettel arra, hogy a szűrés nélküli pontfelhő esetében a mérési 
vagy interpolált pont közvetlen környezetében a sugárzási érték átmenet nélkül vált a mért értékről nullára, majd újra a következő pont mért értékére, a konvolúciós szűrő (például egy egyszerü $\mathrm{n} \times \mathrm{m}$ terület átlagolása) a valósághoz közelítő eredményt szolgáltat.

További korrekcióval a háttérsugárzás értékét is el kell távolítani. Ennek módszere viszonylag egyszerű. Feltételezve, hogy a mérés során a terület nagyobb része csak háttérsugárzást tartalmaz, az átlagosan mért sugárzási értékeket minden mérési pontból ki kell vonni. Ekkor vagy egy, a detektor érzékenységi szintjénél lényegesen alacsonyabb értékeket tartalmazó képünk lesz (ebben az esetben a vizsgált területen nem volt sugárforrás), vagy megmarad néhány kiugró érték, ami a vizsgált területen feltárt sugárforrást jelenti.

\section{KísÉRLETI EREDMÉNYEK}

A kísérletek során Tc-99m izotóp mintát alkalmaztunk. Ennek előnye, hogy 6 órás felezés idejének köszönhetően, a minta elkészítését követően marad elég idő a mérés helyszínére jutáshoz és a kísérletek elvégzéséhez, ugyanakkor kellően hamar lebomlik. A minták aktivitása minden kísérlet során az úgynevezett mentességi aktivitás alatti volt, azaz speciális engedélyhez nem kötött (a 2005. évi atomtörvény hatálya alá nem tartozik). Az ilyen kis aktivitású minta kellően biztonságos, de nagyobb távolságból történő kimutatása csak érzékeny detektorok segítségével lehetséges. A minta a mérés megkezdésekor $221 \mu$ Svh aktivitású volt (5. ábra).

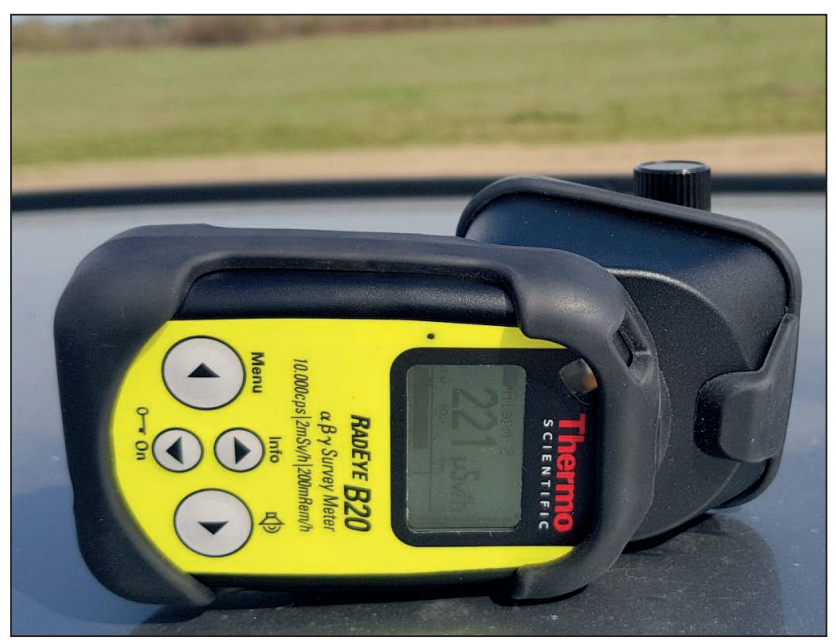

5. ábra. A minta aktivitásának mérése a kísérlet megkezdése előtt

A 6. ábra egy kísérlet repülési nyomvonalát szemlélteti. A repülés a minta felett 9 méter magasan $( \pm 0.1 \mathrm{~m})$ történt. A repülés sebessége $2 \mathrm{~m} / \mathrm{s}( \pm 0.1 \mathrm{~m} / \mathrm{s})$ volt. A vizsgált terület megközelítőleg $80 \times 80$ méter, azaz $6400 \mathrm{~m}^{2}$. Az ábrán látható pontsűrűsödés a fel- és leszállás helye, ahol a drón már nem egyenletes sebességgel haladt. Az ezen a ponton gyűjtött mérési adatokat a feldolgozás során nem használtuk.

$A z$ adatok mennyiségének növelése érdekében a területet az eszköz kétszer pásztázta végig úgy, hogy a repülés második szakaszában a nyomvonalak merőlegesek voltak a repülés első szakaszának nyomvonalaira. Ennek megfelelően a kialakult repülési nyomvonal egy négyzetrácsot eredményez. A 6. ábrán látható nyomvonalat utólag a tény-

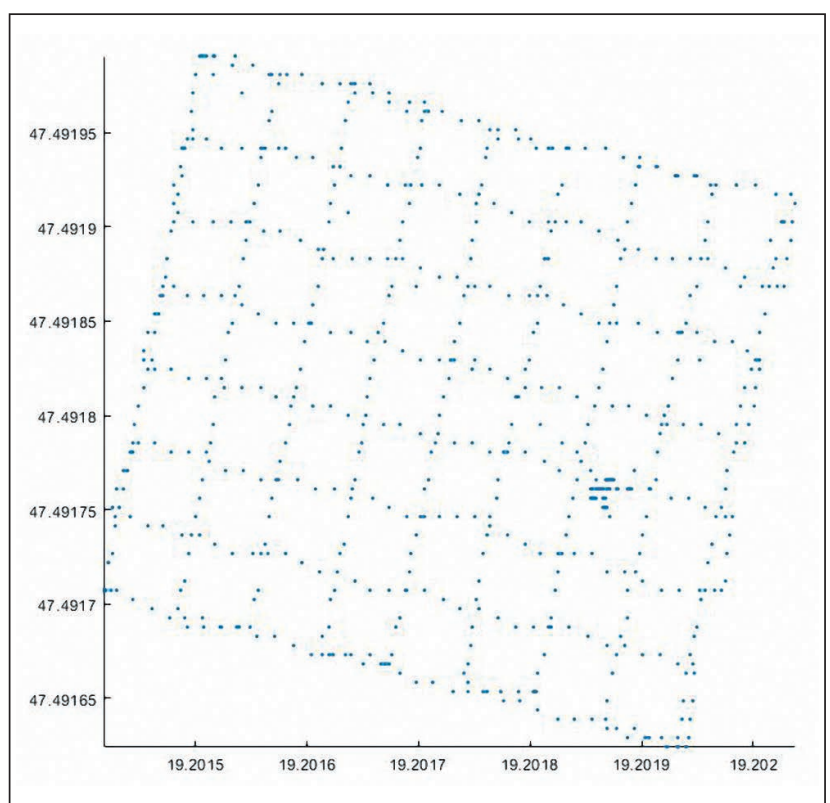

6. ábra. Egy mérés repülési nyomvonala

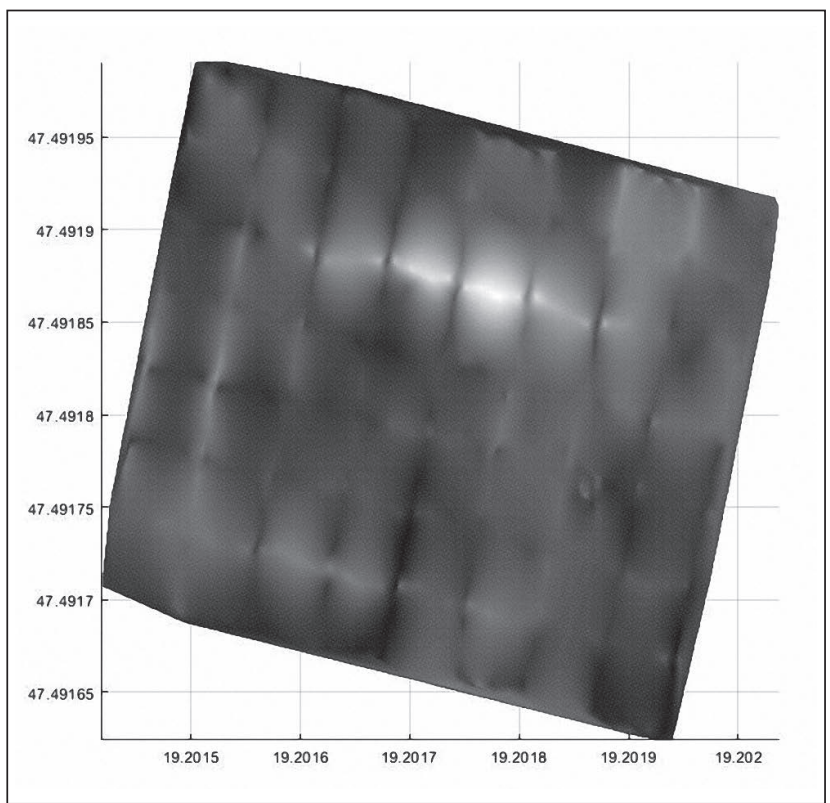

7. ábra. A nyers beütésszámok alapján létrehozott sugárzási kép

leges repülés során rögzített GPS-adatok alapján rekonstruáltuk.

A nyers mérési adatok alapján létrehozott sugárzás eloszlását a 7. ábra szemlélteti. Az adatok ebben az esetben semmiféle korrekción nem estek át.

A képen jól látható a repülési nyomvonalból adódó négyzetrács, ami a mozgási korrekció hiánya miatt jelenik meg. További hiba, hogy a háttérsugárzással sem korrigáltuk a mért adatot, így annak hatása is megjelenik a képen, ami téves sugárforrásra utaló jeleket eredményez.

A 8. ábra a mért adatok konvolúciós szűrését követően készült. A szűrés egyéb korrekciókat nem tartalmazó adatokon történt, hogy jól érzékelhető legyen annak hatása. Az ábrán látható ugyan nagyobb aktivitásra utaló terület, de annak pontos lokalizációja még nem lehetséges. Mivel a haladási korrekció sem történt meg, az egyetlen pontból 


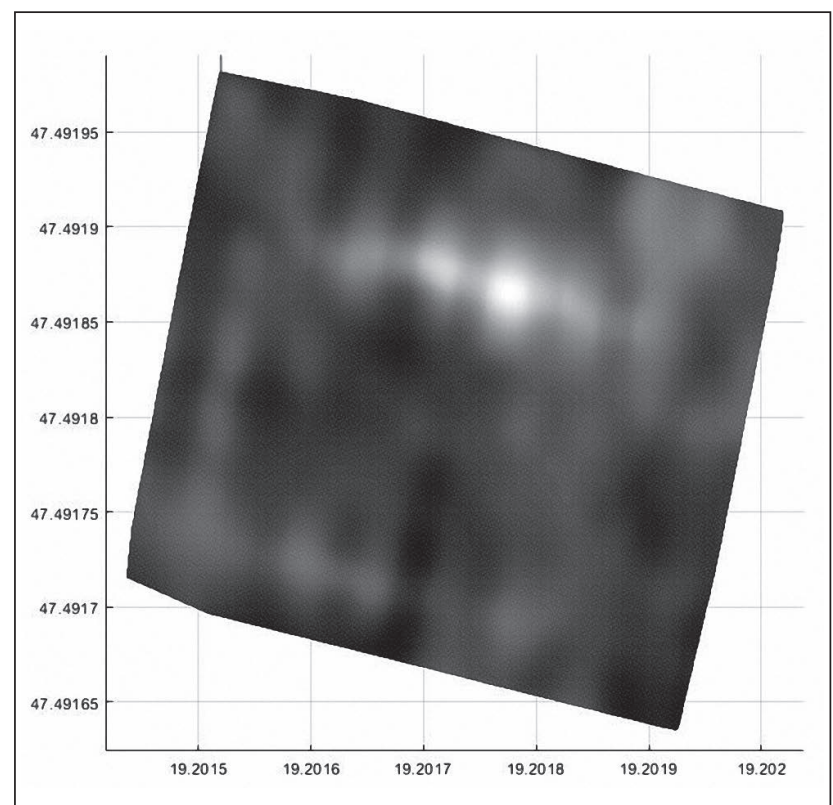

8. ábra. Szürt beütésszámok alapján létrehozott sugárzási kép

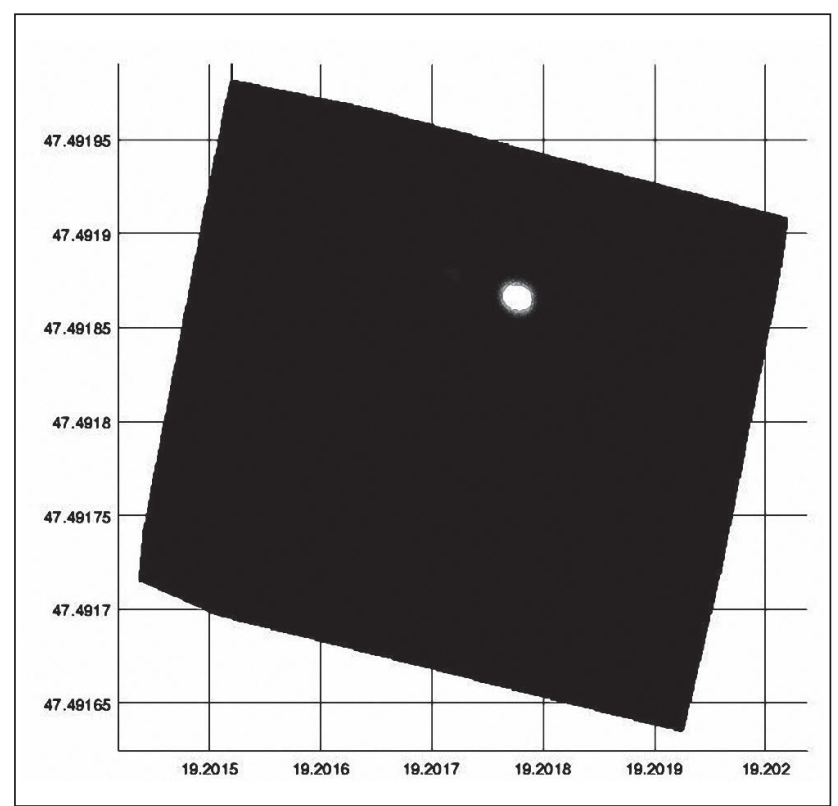

9. ábra. Korrigált sugárzási kép

álló sugárforrás egy elmosott, hosszanti részre terül szét. Amennyiben ismeretlen területen történne a mérés, és csupán a 8. ábrán látható módon történne a sugárzás eloszlásának ábrázolása, tévesen nagy területet lehetne a kép alapján megjelölni.

A 9. ábra a háttérsugárzás és a mozgásból adódó koordináta-korrekciót és a háttérsugárzás levonását követően szemlélteti a sugárzás eloszlását a vizsgált területen.

$A z$ ábrán (9. ábra) látható sugárzási folt a háttér beütésszámának kétszerese, azaz szignifikáns jel a mért területen. A vizsgálat során a háttérsugárzásra átlagosan $80 \mathrm{cpm}$ (percenkénti részecskedetektálás az angol terminológia szerint Count Per Minute) adódott, míg a minta felett ez a beütésszám átlagosan $172 \mathrm{cpm}$ volt.

A 10. ábrán a georeferált ortofotóra vetített korrigált sugárzási kép látható. A georeferált ortofotó a drón fedélzeti

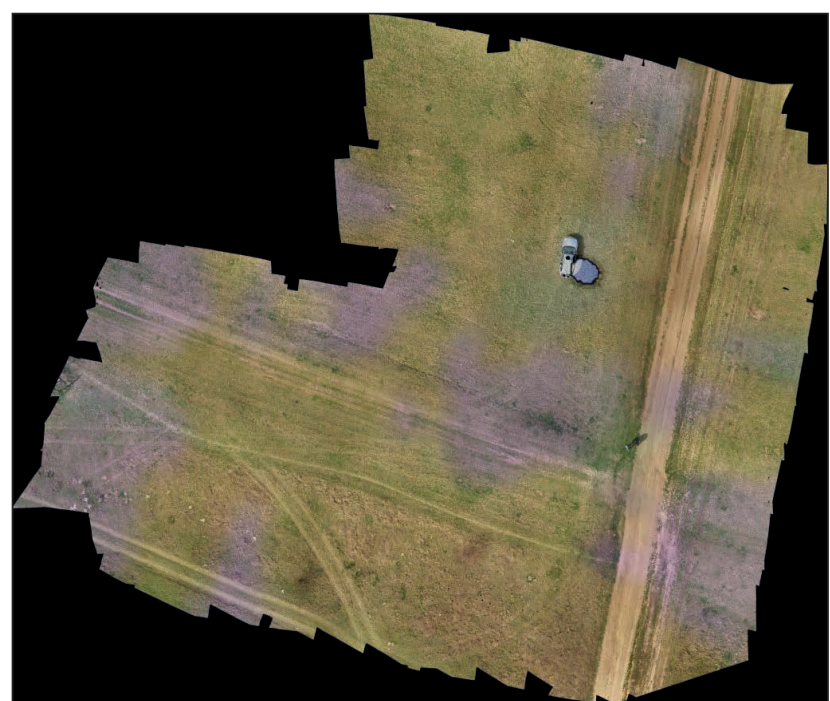

10. ábra. Georeferált ortofotó a sugárzási képpel kombinálva

kamerájának képei alapján készült. Mivel a kamera nem függőleges tengelyre volt pozícionálva $\left(90^{\circ}\right.$ helyett $\left.80^{\circ}\right)$, a berepült területtől nagyobb területről állt rendelkezésre képi információ, ami megkönnyíti az ortofotó kalibrációját.

A minta a képen (10. ábra) látható személygépkocsi tetejére volt helyezve. Látható, hogy a sugárforrás a mérés alapján kissé a személygépkocsi mellett jelenik meg. Több mérés kiértékelése során azt tapasztaltuk, hogy az eltérés változó irányokban maximum 1,5 méter volt a tényleges minta helyétől. Ez az eltérés részben az alkalmazott GPS mérési hibájából, valamint a mozgás korrekciójának pontatlanságából adódik.

\section{TAPASZTALATOK}

A kísérletek során bebizonyosodott, hogy kvalitatív módon a sugárforrás szabad téren történő lokalizálása a projekt eredeti minőségi elvárásainak megfelelően lehetséges. A módszer által megjelölt helyen kézi műszerrel már könynyen megtalálható a keresett sugárzó anyag.

A módszer hatékonyságának növelése érdekében növelni kell a sugárdetektor érzékenységét. Nagyobb érzékenységű detektorrendszer esetében (amennyiben az nem jár jelentős tömegnövekedéssel) növelhető a vizsgált terület feletti repülési sebesség. A nagyobb sebesség nagyobb berepülhető területet jelent, így a jelenleg elért $6400 \mathrm{~m}^{2}$ terület akár $10000 \mathrm{~m}^{2}$-re növelhető. A nagyobb érzékenységü detektor nagyobb magasságból történő felmérést is lehetővé tesz, ami az alkalmazási területek bővülését jelenti. Nagyobb vizsgálati magasság esetén kisebb épületekkel fedett terület felett is elvégezhető a mérés, ami jelen esetben elsősorban parkolók, gépjárművek vagy egyéb nem nagy magasságú tereptárgyakkal fedett terület felett végezhető csak el.

A detektor megfelelő kalibrációja esetén a sugárzás eloszlását szemléltető térkép színezése az adott ponton számított aktivitással lehet arányos, ami kvantitatív mérésekre is lehetőséget biztosít. Egy továbbfejlesztett feldolgozó szoftverrel lehetőség nyílik kvantitatív információkkal ellátott dózisteljesítmény eloszlási térkép előállítására.

(Köszönet illeti a Semmelweis Egyetem Nukleáris Medicina Központot, valamint a Semmelweis Egyetem Sugárvédelmi Szolgálatot, hogy a mérésekhez izotóp mintát és szakmai segítséget biztosítottak.) 


\section{FELHASZNÁLT IRODALOM}

[1] Šálek, O., Matolín, M., Gryc, L.: Mapping of radiation anomalies using UAV mini-airborne gamma-ray spectrometry (2018) Journal of Environmental Radioactivity, 182, pp. 101-107, DOI: 10.1016/j. jenvrad.2017.11.033;

[2] Sato, Y., et al.: Remote radiation imaging system using a compact gamma-ray imager mounted on a multicopter drone (2018) Journal of Nuclear Science and Technology, 55 (1), pp. 90-96, DOI: 10.1080/00223131.2017.1383211;

[3] Lazna, T., Gabrlik, P., Jilek, T., Zalud, L.: Cooperation between an unmanned aerial vehicle and an unmanned ground vehicle in highly accurate localization of gamma radiation hotspots (2018) International Journal of Advanced Robotic Systems, 15 (1), DOI: 10.1177/1729881417750787;

[4] Mochizuki, S. et al.: First demonstration of aerial gamma-ray imaging using drone for prompt radiation survey in Fukushima (2017) Journal of Instrumentation,
12 (11), art. no. P11014, DOI: 10.1088/17480221/12/11/p11014;

[5] Aleotti, J. et al.: Detection of nuclear sources by UAV teleoperation using a visuo-haptic augmented reality interface (2017) Sensors (Switzerland), 17 (10), art. no. 2234, DOI: 10.3390/s17102234;

[6] Hinterhofer, T., Pfennigbauer, M., Schraml, S. Hofstätter, M.: UAV based multi-sensor system with real-time data processing and downlink for survey of nuclear disaster locations for first-responder support (2017) AUVSI XPONENTIAL 2017;

[7] Stojcsics D., Molnár A.: AirGuardian - UAV Hardware and Software System for Small Size UAVs International Journal of Advanced Robotic Systems 9: pp. 1-8. (2012), DOI: 10.5772/52759;

[8] Somlyai L., Turóczi A., Molnár A.: Atmospheric Analyser for Mobile Robots, Proceedings of The 13th IEEE International Symposium on Computational Intelligence and Informatics: CINTI 2012. Budapest, 2012. pp. 181-185. DOI: 10.1109/cinti.2012.6496756.

\section{Siposné Kecskeméthy Klára - B. Kalavszky Györgyi}

\section{A Ludovika egykor és most}

2018-ban, a Zrínyi Kiadó gondozásában jelent meg A Ludovika egykor és most című kötet. A szerzők - Siposné dr. Kecskeméthy Klára és B. Kalavszky Györgyi - nem kisebb feladatra vállalkoztak, mint hogy feldolgozzák a magyar tisztképzés fellegvárának, az egykori magyar királyi Ludovika Akadémiának történetét, és széles körű betekintést nyújtsanak az egykori katonai akadémia szellemiségébe és hagyományaiba. A szerzőpáros $A$ Ludovika című könyve 2011-ben jelent meg először, majd ezt követte két évre rá a kiadvány javított utánnyomása. A második, bővített kiadás tavaly került a könyvesboltok polcaira.

A mű első része a Magyar Királyi Honvéd Ludovika Akadémia történetét dolgozza fel az 1808-as évi törvényben megfogalmazott alapítási tervektől, egészen 1945-ig. Bemutatja az egykori felvételi rendszert, az iskola nevelési értékrendjét és képzési rendszerét, a kiképzés menetét, az Akadémián folyó sport- és kulturális életet, az avatást és az iskola ünnepi rendezvényeit. $A z$ áttekintést számos fotó illusztrálja.

A második rész a ludovikás hagyományok újjáéledéséről számol be az 1990 utáni időszakban, a Zrínyi Miklós Nemzetvédelmi Egyetemen. Itt gyűjtöttek össze minden információt, amely a Ludovika-zászló hazatérésével, és az MH Ludovika Zászlóalj megalakulásával kapcsolatos.

A közelmúltban kiadott második kiadás jelentős tartalommal gazdagodott. A könyv harmadik, befejező része a Nemzeti Közszolgálati Egyetem 2012-es megalakulását követő időszak eseményeit tárgyalja. Kiemelt figyelmet szentelnek a Ludovika épületegyüttes és az Orczy-park rekonstrukciójának, a Ludovika Egyetemi Campus kiépülésének.

Siposné dr. Kecskeméthy Klára, a kötet egyik szerzője az egykori ludovikás növendékeknek ajánlotta a könyvet. Mint írja, a második világháborút követő évtizedekben megaláztatások sora érte őket, amelynek ellenére büszkén vállalták tiszti múltjukat. A könyv egyik célja éppen az, hogy ezek az emberek - érezve a társadalmi megbecsülést - a sors megkésett igazságszolgáltatásának tekintsék a művet.

A könyv másik fő célja a ludovikás szellemiség megismertetése az újabb nemzedékekkel, amely azóta sem változott: hazaszerető és szakmailag felkészült honvédtisztek képzése a jövő számára. A kötet köszöntőjében a 102 éves vitéz Koós Ottó nyugalmazott alezredes, 1934 és '38 között az intézmény hallgatója, így fogalmaz: „A Ludovika Akadémia nemes eszményeket képviselt, magas szintű szaktudással vértezte fel hallgatóit, hazaszerető, erkölcsös, becsületes, bajtársias, jó modorú, sokirányúan művelt tiszteket bocsátott ki. Az itt kiképzett hallgatók, parancsnokok nagyfokú kötelességtudattal, fegyelmezettséggel, bajtársiassággal, tiszteletteljes magatartással és nem utolsó sorban hazaszeretettel élték az életüket."

A 360 oldalas, füzött, keménytáblás, gazdagon illusztrált könyv 9200 Ft-os áron kapható a könyvesboltokban, illetve közvetlenül a Zrínyi Kiadónál is, a kiadó online felületén kedvezményes, 6900 Ft-os áron: http://www.hmzrinyi.hu/termek/a_ludovika_egykor_es_most (Cím: 1087 Budapest, Kerepesi út 29/b, Tel.: 06 1-459-5373, e-mail: gyoredina@armedia.hu). (SzA) 